\title{
PERSEPSI DAN SIKAP MAHASISWA PENDIDIKAN BIOLOGI UMP TERHADAP MATA KULIAH MULTIMEDIA PEMBELAJARAN
}

\author{
Arum Adita \\ Progam Studi Pendidikan Biologi, FKIP, Universitas Muhammadiyah Purwokerto \\ Kampus I, J1.Raya Dukuhwaluh Purwokerto 53182, Jawa Tengah, Indonesia \\ surat elektronik: aroemdita@gmail.com
}

\begin{abstract}
ABSTRAK
Multimedia pembelajaran merupakan mata kuliah pilihan untuk membekali calon guru terhadap penguasaan teknologi pembelajaran. Hal ini sesuai dengan learning outcomes yang dirumuskan oleh pendidikan biologi Universitas Muhammadiyah Purwokerto (UMP) bahwa lulusan diharapkan menjadi tenaga pendidik yang berinovasi untuk meningkatkan mutu pendidikan biologi (kompetensi pedagogik). Tujuan dari penelitian ini adalah untuk mengetahui persepsi dan sikap mahasiswa terhadap mata kuliah multimedia pembelajaran. Penelitian ini merupakan penelitian deskriptif dengan pendekatan kuantitatif. Subyek penelitian adalah seluruh mahasiswa Pendidikan Biologi UMP berjumlah 32 orang yang mengambil mata kuliah multimedia pembelajaran pada tahun akademik 2015/2016. Instrumen yang digunakan adalah angket untuk mengukur persepsi dan sikap serta dokumen untuk melihat keterampilan menyusun media. Angket yang digunakan memiliki alfa cronbach 0,83 yang berarti instrumen reliabel. Validasi dilakukan dengan expert judgement. Teknik analisis data yang digunakan dengan analisis deskriptif kuantitatif. Persepsi dan sikap mahasiswa terhadap pembelajaran multimedia dalam kategori cukup. Hal ini ditunjukkan dari tanggapan responden terhadap item-item persepsi mahasiswa tentang multimedia pembelajaran dengan presentase $64,2 \%$ dan tanggapan responden terhadap item-item sikap mahasiswa tentang multimedia pembelajaran dengan persentase $72,19 \%$.
\end{abstract}

Kata kunci: persepsi, sikap, multimedia pembelajaran

\section{Pendahuluan}

Integrasi Teknologi Informasi dan Komunikasi (TIK) ke dalam pembelajaran perlu dilakukan. Tuntutan ini merujuk pada tuntutan abad 2I bahwa peserta didik harus memiliki TIK (ICT) skills. Hal ini diperkuat dengan adanya Undang- Undang yang menghimbau agar dalam pelaksanaan pembelajaran memanfaatkan teknologi informasi.

Integrasi TIK dalam pembelajaran dapat meningkatkan keefektifan proses belajar mengajar terutama dalam pembelajaran sains seperti biologi, kimia, maupun fisika (Aina, 2013, p. 46). Menurut (Keengwe \& Hussein, 2013, p. 75) peserta didik yang belajar menggunakan CAI (Computer Assited Instruction) sebagai suplemen menunjukkan hasil yang lebih baik dari pembelajaran tradisional. Hal ini didukung pula oleh karakter peserta didik saat ini yang tergolong digital natives (tumbuh dan berkembang dalam lingkungan teknologi informasi).

Berdasarkan hal tersebut sudah menjadi keharusan seorang guru untuk mengembangkan kompetensinya melalui ICT skills. Penelitian Dopo \& Ismaniati (2015, p. 23) menunjukkan bahwa persepsi guru terhadap digital natives berpengaruh terhadap motivasi guru dalam memanfaatkan sumber belajar digital. Pengelolaan sumber belajar digital termasuk di antaranya adalah memanfaatkan multimedia berbasis komputer dalam pembelajaran.
Pembelajaran multimedia merupakan model yang menggabungkan teknologi untuk memfasilitasi guru dan peserta didik dalam meningkatkan proses pembelajaran. Multimedia dapat meningkatkan kapasitas working memory, yakni kemampuan otak untuk memproses informasi. Otak dapat memproses informasi dengan cepat apabila informasi yang disajikan dalam bentuk visual dan verbal (Mayer, 2009, p. 64).

Pembelajaran multimedia juga dapat membantu guru dalam menciptakan pembelajaran yang lebih baik. Program-program komputer dapat digunakan untuk membuat media pembelajaran interaktif dalam dunia pendidikan. Sehingga hal ini akan menumbuhkan motivasi para pelaku dalam bidang pendidikan untuk membuat media pembelajaran interaktif yang lebih variatif dan inovatif (Srinivasan \& Crooks, 2005, p. I64). Selain itu pembelajaran multimedia dapat mengakomodir peserta didik dengan kecerdasan ganda melalui multimedia interaktif (Bull, 2013, p. 617).

Melalui pembelajaran multimedia, guru memfasilitasi peserta didik untuk belajar menghubungkan informasi baru ke dalam sistem kognitif mereka dan membuatnya paham. Hal tersebut dikemukakan oleh Yazdi dan Zandkarimi (2013, p. 54) dan Khoiriah (2016, p. 80) bahwa terdapat hubungan yang signifikan antara kognitif dan penggunaan teknologi. Studi oleh Mulyani, et al., (2016, p. I55) menunjukkan bahwa multimedia yang didesain seperti 
virtual laboratory dapat meningkatkan keterampilan umum sains. Hal ini sejalan dengan pemikiran konstruktivistik bahwa pengetahuan yang diperoleh peserta didik diperoleh dari pengalaman-pengalamannya yang membentuk menjadi bangunan konsep yang utuh. Schilling (2009, p. 224) mengemukakan bahwa melalui pembelajaran multimedia, pendidik dapat meningkatkan kualitas pengajaran dan dapat menyiapkan peserta didik untuk berpikir kritis dan problem solving.

Berdasarkan hasil penelitian Tiawa, et al., (2012, p. 130) diketahui bahwa belum banyak guru yang menerapkan multimedia dalam pembelajaran sains. Hal tersebut menjadi tantangan bagi calon pendidik saat ini. Menurut Ozdamli et al., (2009, p. 462) pengetahuan tentang media instruksional penting dipelajari oleh guru maupun calon guru. Kedepannya penggunaan multimedia tersebut akan meningkatkan proses belajar mengajar menjadi lebih efektif (Nachimutu \& Vijayakumari, 2012, p. I72). Oleh karena itu pembelajaran multimedia menjadi penting terutama untuk guru dan calon guru.

Sejalan dengan hal tersebut pembelajaran multimedia sudah diajarkan di Pendidikan Biologi Universitas Muhammadiyah Purwokerto, multimedia pengajaran merupakan mata kuliah pilihan untuk membekali calon guru terhadap penguasaan teknologi pembelajaran. Hal ini sesuai dengan learning outcomes yang dirumuskan oleh pendidikan biologi UMP bahwa lulusan yang diharapkan menjadi tenaga pendidik yang berinovasi untuk meningkatkan mutu pendidikan biologi (kompetensi pedagogik). Tenaga pendidik yang dimaksud adalah memiliki kemampuan untuk menerapkan konsep biologi dan teknologi kependidikan dengan memanfaatkan kemajuan IPTEKS untuk membuat produk-produk pembelajaran dalam mendukung terselenggaranya pembelajaran biologi. Salah satu keberhasilan perkuliahan dapat dilihat dari persepsi dan sikap mahasiswa dalam pembelajaran multimedia. Seperti yang diutarakan Shulman (1987,p.8) bahwa pengetahuan tentang siswa dan karakter siswa merupakan salah satu faktor penentu keberhasilan pembelajaran. Tujuan dari penelitian ini adalah untuk melihat bagaimana persepsi dan sikap mahasiswa terhadap pembelajaran multimedia.

\section{Metode Penelitian}

Penelitian ini merupakan penelitian deskriptif dengan pendekatan kuantitatif. Subjek penelitian adalah seluruh mahasiswa yang mengambil mata kuliah multimedia pembelajaran berjumlah 32 orang pada tahun akademik 2015/2016. Teknik pengambilan data dengan menyebar angket dan dokumen. Angket yang digunakan merupakan angket tertutup dengan modifikasi skala likert yang terdiri dari empat pilihan : Sangat setuju (SS) skoring 4, Setuju (S) skoring 3, Kurang Setuju (KS) skoring 2 dan Tidak Setuju (TS) skoring I. Angket digunakan untuk mengumpulkan data tentang persepsi dan sikap mahasiswa sedangkan dokumen untuk melihat keterampilan mahasiswa dalam menyusun multimedia. Angket yang digunakan memiliki alfa cronbach 0,83 yang berarti instrumen reliabel. Validasi dilakukan dengan expert judgement yang melibatkan dosen ahli media.

Teknik analisis data yang digunakan dengan analisis deskriptif kuantitatif. Variabel persepsi dan sikap digambarkan dalam tabel deskripsi frekuensi (Tabel.2) dengan kategori penilaian sebagai berikut :

Tabel 1. Kategori Persentase

\begin{tabular}{ll}
\hline \multicolumn{1}{c}{ Kategori } & \multicolumn{1}{c}{ Persentase } \\
\hline Baik & $76 \%-100 \%$ \\
Cukup & $56 \%-75 \%$ \\
Kurang Baik & $40 \%-55 \%$ \\
Tidak Baik & Kurang dari $40 \%$ \\
\hline
\end{tabular}

(Dopo \& Ismaniati, 2015, p. I7)

\section{Hasil dan Pembahasan}

Persepsi mahasiswa dalam pembelajaran multimedia diketahui dari aspek penerimaan, pemahaman dan penilaian mahasiswa terhadap pembelajaran multimedia, sedangkan sikap dilihat dari sikap memahami, senang dan kecenderungan bertindak. Hal ini didasarkan rumusan Eagly \& Chaiken (1993, p.I0) bahwa sikap seseorang atau respon seseorang terhadap objek dapat dibagi menjadi tiga yaitu cognitive responses, affective responses, dan behavioral responses.

Tabel 2. Deskripsi tanggapan responden terhadap itemitem persepsi.

\begin{tabular}{|c|c|c|c|c|c|c|c|c|c|c|}
\hline \multirow{2}{*}{ Aspek } & \multirow{2}{*}{ item } & ss & \multicolumn{2}{|c|}{$\mathrm{s}$} & \multicolumn{2}{|c|}{ TS } & \multicolumn{2}{|c|}{ STS } & \multirow{2}{*}{$\mathrm{n}$} & \multirow{2}{*}{ skor } \\
\hline & & $\%$ & f & $\%$ & f & $\%$ & f & $\%$ & & \\
\hline \multirow{5}{*}{ aspek penerimaan } & item 1 & 27,14 & 10 & 35,71 & 16 & 57,14 & 0 & 0 & 28 & 70 \\
\hline & item 2 & 0 & 6 & 21,43 & 22 & 78,57 & 0 & 0 & 28 & 62 \\
\hline & item 3 & 0 & 15 & 53,57 & 12 & 42,86 & 1 & 3,57 & 28 & 70 \\
\hline & item 4 & 0 & 18 & 64,29 & 10 & 35,71 & 0 & 0 & 28 & 74 \\
\hline & item 5 & 0 & 15 & 53,57 & 11 & 39,29 & 2 & 7,14 & 28 & 69 \\
\hline \multirow{9}{*}{ aspek pemahaman } & item 6 & 0 & 5 & 17,86 & 22 & 78,57 & 1 & 3,57 & 28 & 60 \\
\hline & item 7 & 27,14 & 22 & 78,57 & 4 & 14,29 & 0 & 0 & 28 & 82 \\
\hline & item 8 & 13,57 & 19 & 67,86 & 8 & 28,57 & 0 & 0 & 28 & 77 \\
\hline & item 9 & 0 & 22 & 78,57 & 6 & 21,43 & 0 & 0 & 28 & 78 \\
\hline & item 10 & 13,57 & 17 & 60,71 & 10 & 35,71 & 0 & 0 & 28 & 75 \\
\hline & item 11 & 13,57 & 22 & 78,57 & 5 & 17,86 & 0 & 0 & 28 & 80 \\
\hline & item 12 & 0 & 22 & 78,57 & 6 & 21,43 & 0 & 0 & 28 & 78 \\
\hline & item 13 & $0 \quad 0$ & 16 & 57,14 & 12 & 42,86 & 0 & 0 & 28 & 72 \\
\hline & item 14 & 13,57 & 22 & 78,57 & 5 & 17,86 & 0 & 0 & 28 & 80 \\
\hline aspek penilaian & item 15 & 13,57 & 13 & 46,43 & 14 & 50 & 0 & 0 & 28 & 71 \\
\hline \multicolumn{9}{|c|}{ Jumlah skor } & & 1098 \\
\hline \multicolumn{9}{|c|}{ Rata-rata skor } & & 73,2 \\
\hline
\end{tabular}

Berdasarkan hasil tanggapan responden terhadap aspek penerimaan diketahui bahwa rata-rata skor 67,8 dengan jumlah skor II2 diperoleh persentase $60,5 \%$. Hal ini menunjukkan bahwa indikator penerimaan berada dalam rentang cukup. Item 4 dalam aspek penerimaan memperoleh skor yang paling tinggi. Item tersebut menunjukkan bahwa penerimaan materi oleh mahasiswa diterima dengan jelas. Hasil yang cukup juga diperoleh dari aspek pemahaman dan penilaian. Rata-rata aspek pemahaman adalah 73,6 dengan persentase 65,7\% sedangkan aspek penilaian diperoleh rata-rata skor 7I dengan persentase 63,3\%. Skor tertinggi pada aspek pemahaman yaitu pada item 7 yang menunjukkan bahwa 
mahasiswa belum memahami penyusunan media menggunakan Adobe Flash.

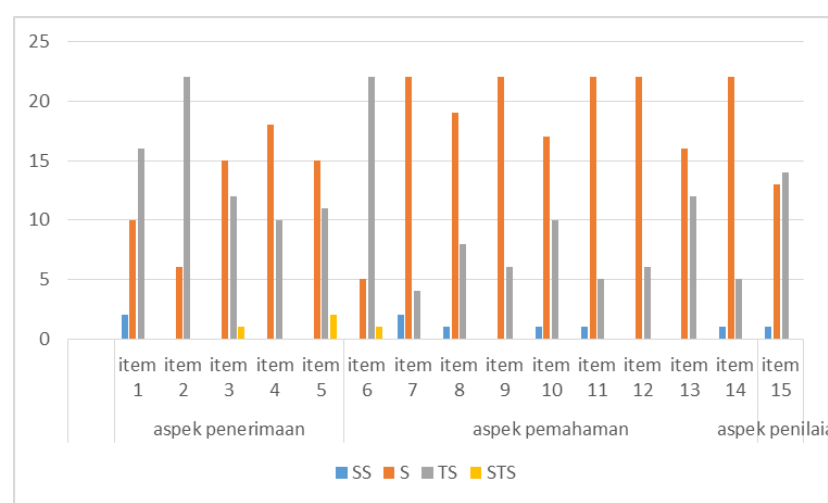

Gambar I. Persepsi mahasiswa dilihat dari aspek penerimaan, pemahaman dan penilaian.

Secara keseluruhan rata-rata dari persepsi mahasiswa adalah 7I,93 sehingga diperoleh presentase 64,2\% yang berarti persepsi mahasiswa berada dalam kategori cukup. Mengenai sikap peserta didik terhadap pembelajaran memiliki kriteria cukup ditunjukkan dengan persentase $72,19 \%$ dengan rata-rata skor 80,85 . Item tertinggi pada skor sikap diperoleh pada aspek untuk kecenderungan bertindak pada item I3. Item tersebut menunjukkan kecenderungan bertindak mahasiswa untuk mengerjakan projek bersama kelompok.

Tabel 3. Deskripsi tanggapan mahasiswa terhadap itemitem sikap.

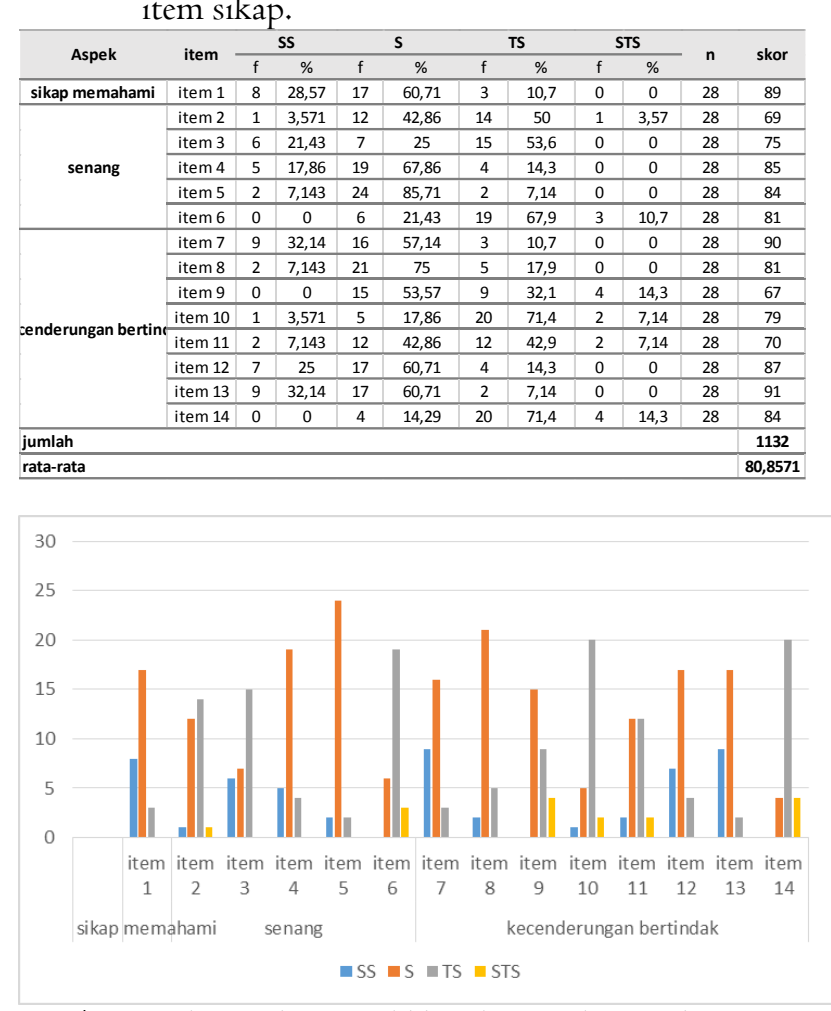

Gambar 2. Sikap mahasiswa dilihat dari aspek memahami, rasa senang dan kecenderungan bertindak

Hasil yang belum maksimal ini perlu menjadi koreksi. Seperti yang diungkapkan oleh Ozdamli (20II, p. 38I7) bahwa untuk mengekfektifkan penggunaan media instruksional perlu dilakukan pembelajaran dengan project-based learning, penguasaan internet dan penggunaan multimedia. Berdasarkan penelitian yang telah dilakukan bahwa mahasiswa masih kesulitandalam menerapkan multimedia berbasis flash. Kendalanya adalah mahasiswa belum terbiasa dengan menyusun media menggunakan flash. Media yang terbiasa digunakan adalah powerpoint. Strategi dalam menerapkan media berbasis flash juga perlu diperbaiki. Penggunaan project-based learning sudah dilakukan tetapi belum sesuai yang diharapkan.

Pembelajaran yang telah dilakukan berawal dari analisis masalah yang ditemui mahasiswa selama kegiatan PPL. Setelah menemukan permasalahan, mahasiswa menentukan tujuan dan jenis teknologi apa yang akan digunakan. Teknologi diarahkan kepada penggunaan media Flash. Mahasiswa kemudian membuat desain multimedia yang akan dikembangkan dalam storyboard. Desain tersebut kemudian dikembangkan lagi dengan membuat aset-aset. Mahasiswa tidak terbiasa dengan software untuk menggambar, sehingga kegiatan penyusunan media membutuhkan lebih banyak waktu. Setelah membuat aset atau gambar, Mahasiswa menyusunannya dalam media flash (Adobe flash). Kegiatan menyusun dan membuat animasi dipandu oleh dosen terlebih dahulu. Selain mendapatkan materi dari dosen, mahasiswa berusaha memanfaatkan sumber belajar lain seperti dari youtube maupun situs-situs tutorial di dunia maya. Berdasarkan media yang dikumpulkan mahasiswa diketahui bahwa mahasiswa mampu menyusun multimedia dengan menggunakan Adobe Flash.

Penelitian ini tidak membedakan persepsi dan sikap mahasiswa berdasarkan gender. Hal ini didasarkan pada penelitian Nachimutu \& Vijayakumari (20I2, p. I72) yang mengemukakan bahwa perbedaan gender tidak berpengaruh terhadap persepsi pelajar pada multimedia. Data menunjukkan bahwa persentase sikap lebih tinggi dibanding persepsinya, walaupun perbedaannya tidak begitu jauh karena masih berada dalam rentang cukup. Berdasarkan hasil penelitian tersebut pembenahan kualitas pembelajaran diperlukan untuk mendukung mahasiswa calon guru dalam memanfaatkan sumber belajar digital. Seperti yang diungkapkan oleh (Dopo \& Ismaniati, 2015, p. 22) bahwa persepsi seorang guru menjadi prediktor penting bagi motivasi guru dalam memanfaatkan sumber belajar.

\section{Simpulan}

Berdasarkan penelitian yang telah dilakukan dapat disimpulkan bahwa persepsi dan sikap mahasiswa pendidikan biologi UMP tahun akademik 2015/2016 terhadap pembelajaran multimedia dalam kategori cukup. 


\section{Daftar Pustaka}

Aina, J. K. (2013). Effective Teaching and Learning in Science Education through Information and Communication Technology (ICT). Journal of Research \& Method in Education (IOSR-JRME), 2(5 (Jul.-Aug.)), $43-47$.

Bull. (2013). Cognitive Costructivist Theory of Multimedia: Designing Teacher-Made Interactive Digital. Journal of Creative Education Vol.4, No. 9.

Dopo, F. B., \& Ismaniati, C. (2015). Persepsi Guru Tentang Digital Natives, Sumber Belajar Digital dan Motivasi Memanfaatkan Sumber Belajar Digital. Jurnal Inovasi Teknologi Pendidikan, 3 No I(April), 13-24.

Eagly, A.H \& Chaiken, S. (1993). The Psychology of Attitudes. New York : Harcourt Brace Javanovich College Publishers.

Keengwe, J., \& Hussein, F. (2013). Computer-Assisted Instruction: A Case Study of Two Charter Schools. International Journal of Information and Communication Technology Education 9(I), 70-79.

Khoiriah. (2016). The Effect of Multimedia-Based Teaching Materials in Science Toward Students' Cognitive Improvement. Jurnal Pendidikan IPA Indonesia, 5 (I), 75-82. doi: 10.15294/jpii.v5i1.5793

Mayer, R. E. (2009). Multimedia Learning. New York: Cambridge University Press.

Mulyani, S., Liliasari, Wiji, Hana, M. N., \& E.Nursa'adah. (2016). Improving Students' Generic Skill in Science Through Chemistry Learning using ICT-Based Media On Reaction Rate and Osmotic Pressure Material. Jurnal Pendidikan IPA Indonesia, 5 (I)(April), I50-156. doi: IO.15294/jpii.v5iI.5804

Nachimutu, K., \& G.Vijayakumari. (2012). Perceptions on Multimedia technology by College of Education Teachers. Journal of Education and Learning Vol. 6 (3), I67-I76.

Ozdamli, F. (20II). The experiences of teacher candidates in developing instructional multimedia materials in project based learning. Procedia Social and Behavioral Sciences, I5 (20II) 3810-3820.

Ozdamli, F., Hursen, C., \& Ozcinar, Z. (2009). Teacher candidates' attitudes towards the instructional technologies. Procedia Social and Behavioral Sciences, I, 455-463.

Schilling, K. (2009). The Impact of Multimedia Course enhancements on Student Learning Outcomes. Journal of Education for Library and information Science 214.

Shulman. (1987). Knowledge and Teaching: foundations of the new reform. Harvard Educational Review, Vol.57,No. I, I-22

Srinivasan, S., \& Crooks, S. (2005). Multimedia in a Science Learning Environment. ProQuest Research Library, pg I5I.

Tiawa, D. H., Mislan, N., Wibowo, S. A., \& Sumintono, B. (20I2). Penggunaan Teknologi Informasi dan Komunikasi dalam Pengajaran: Survei pada Guru-Guru Sains SMP di Indonesia. Jurnal Pengajaran Matematika dan Ilmu Pengetahuan Alam(Vol I7, No I (2012): Jurnal Pengajaran MIPA), I22-I3I.
Yazdi, \& Zandkarimi. (2013). The Impact of E-learning on some Psychological Dimensions and Academic Achievement. International Journal of Education and Learning Vol.2. No.2 49-56. 